\title{
Optimizing of Public Housing Financing Policies for Low Income Community in Indonesia: Conceptual Approach
}

\author{
Noeroso L. Wahyudi \\ Researcher, Centre for Macroeconomic Policy, \\ Fiscal Policy Agency, Ministry of Finance.
}

\begin{abstract}
Evolution on housing finance policies and development of public housing for low income community (MBR) are interesting phenomenon which have inspired a study to optimize its financing strategically. Conceptually, there are two approaches on analyzing on public housing financing policies for MBR, namely: i) the market or supply chain approach, and ii) good governance approach. Market approach is focusing on business supply chain between actors interaction in demand and supply responively. While the approach of good governance or partnership is the interaction among the stakeholders (stakeholders), especially between the agent or regulator with the actors or operators in executing to promote housing development towards more credible and adaptive. This good governance approach is deeply explored in the partnership among financial institutions such as banking, insurance. . To get the findings and recommendations, this paper explores a reference not only on theoretical study, potential financing based on the existing legal basis of potential funding sources qualitively. The next exploration are the developments in the availability of housing for MBR. Analysis of housing finance optimally explores on three (3) sub-topics, namely: i) the target housing finance MBR, ii) the establishment center of revolving fund institution (PPDPP), iii) Secondary Financing Company (PT SMF). Hopefully, implementing these concept could promote public housing development more conducive resulted in less shortage or backlog of apropriate public house for low income society in Indonesia.
\end{abstract}

Keywords: Fiscal, Financing, Public Housing Development. JEL Clasification: F 00,E 62, W 48.

\section{EVOLUTION OF FINANCE AND DEVELOPMENT OF PUBLIC HOUSING}

\section{Evolution of Housing Finance Policies}

One of the references on housing finance policies that can be used is Permenpera (minestry regulation of public work) No.5 / Permen / M / 2007 dated February 9, 2007 on Procurement of Housing and Settlements with the support of housing subsidized facility through KPRS / KPRS Mikro (interest rate subsidi scheme). In general, housing finance policies in Indonesia started in 1976. The evolution of this policy can be described in figure below.

Figure-1: Evolution of Housing Finance Policies in Indonesia

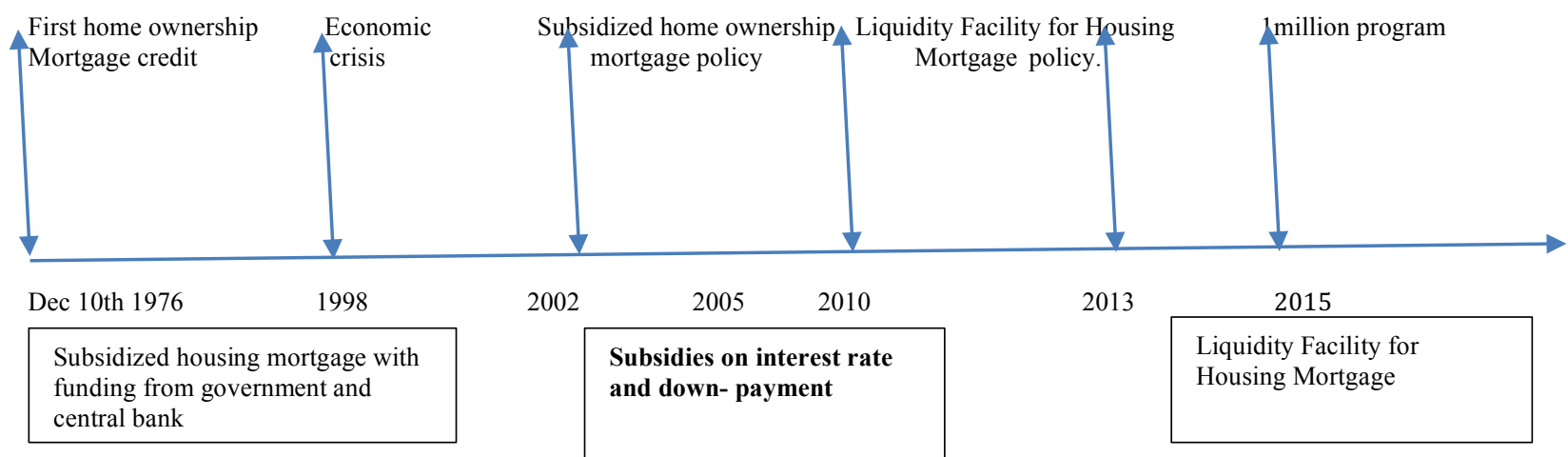

Source: Nugroho Tri Utomo, 2014 
Unfortunately, the program of subsidized development or improvement loan policy (KPRS) targeted for non-fixed income households with maximum monthly income USD 250 terminated in 2009 due to the implementation couldn't meet the good governance requirement (Tri Utomo,2014). This program was participated by 1 national bank, 33 rural banks, and 193 cooperatives.

\section{Recent developments in realization of housing budget allocation for MBR}

Meanwhile the performance of development of public housing can be seen in the table below

Table-1: Realization on Financing (FLPP) on State Budget and public housing for MBR.

\begin{tabular}{|c|l|l|}
\hline Year & \multicolumn{1}{|c|}{$\begin{array}{c}\text { Realization FLPP } \\
\text { (IDR) }\end{array}$} & $\begin{array}{c}\text { Realization } \\
\text { (UNIT) }\end{array}$ \\
\hline 2010 & 242.656 .944 .516 & 7.959 \\
\hline 2011 & 3.688 .272 .535 .411 & 109.592 \\
\hline 2012 & 2.587 .256 .538 .729 & 64.785 \\
\hline 2013 & 5.363 .161 .269 .150 & 102.714 \\
\hline 2014 & 4.655 .625 .834 .824 & 76.057 \\
\hline 2015 & 6.055 .243 .293 .208 & 76.489 \\
\hline 2016 & 5.627 .538 .999 .307 & 58.469 \\
\hline 2017 & 2.706 .624 .492 .776 & 23.763 \\
\hline 2018 & $4,834,330,883,058$ & 46,946 \\
\hline TOTAL & $\mathbf{3 5 , 7 6 0 , 7 1 0 , 7 9 0 , 9 7 9}$ & $\mathbf{5 6 6 , 7 7 4}$ \\
\hline
\end{tabular}

Note: FLPP: Liquidity Facilities for Housing Mortgage

Source: http://ppdpp.id/kinerja-penyaluran-dana-flpp-2/

Table-1 shows that the role of realization of FLPP in IDR to total amount public house unit should be promoted. On average the realization of unit of public house is less than $10 \%$ to public house development targeted by government should be reached 1 million yearly unit since 2015. As a result, there is a need to optimize public house finance to MBR strategically. In other words, there is a need to explore the experience of public housing financing scheme for its lesson learnt. Conceptually, there are two approaches on analyzing on public housing financing policies for MBR, namely: i) the market or supply chain approach, and ii) good governance approach. Market approach is focusing on business supply chain between actors interaction in demand and supply responively. While the approach of good governance or partnership is the interaction among the stakeholders (stakeholders), especially between the agent or regulator with the actors or operators in executing to promote housing development towards more credible and adaptive. This good governance approach is deeply explored in the partnership among financial institutions such as banking, insurance.

\section{Analytical Framework}

As mentioned sub topic 1.1 above, it describes the evolution of financing scheme in housing development program. While in sub-topic 1.2 above, it illustrates a decade of performance for implementation on financing scheme. Conceptually the government's efforts to build supply chains and strengthen institutional governance of financing. Thus, it is necessary to explore government policies and strategic systematically. The objective this exploration to obtain the findings and recommendations of strategicaly steps in optimizing the sources of housing funding to finance an affordable housing prices for MBR. As a result, this analytical framework presents methodology of this paper.

As an explorative study, this paper will present a framework of discussion consisting 4 (four) topics. The first topic is an introduction that presents the problems and solutions of housing development from the aspect of financing. The first topic consists of 3 (three) sub-topics, namely: i), Evolution of finance sheme, ii) Reralization on development public housing based 
on FLPP, iii) analytical framework. Furthermore the second topic will present Housing Development Program This second topic consist of three subs topic, namely i) Definition LowIncome Communities (MBR), ii) Target of housing development for MBR ,iii) The development of housing finance schemes. Furthermore the third topic is analysis of housing financing source of MBR.. This third topic consists of 3 (three) sub-topics, namely: i) Financing Policies and Strategies, ii) Revolving Funds Public Company - Centre of Agency Revolving fund for public housing (BLU - PPDPP), and iii) Partnership Analysis in the concept of Good Corporate Governance.

As the final presentation in this paper, the fourth topic will present the findings and recommendation of strategically steps in optimizing housing funding to finance for MBR.

\section{Definition Low-Income Communities (MBR) \\ HOUSING DEVELOPMENT PROGRAM}

Law No. 1 of 2011 on Housing and Settlement Area (PKP) states that the Government obliges to provide incentive and / or program for MBR (Low Income Society) to get Public House either in the form of single house, or row house, or apartment. This law is expected as a legal basis to find out the problem of shortages or backlogs of apropriate house by 13.6 million units (Census BPS 2010). It implies that then If the shortage of this house must be provided by the Government within 20 years, then the need for house procurement of 460000 units per year. In addition, if every year it needs an additional 800000 units based on population growth, then it is necessary to provide housing for 1260000 units yearly. Officially solve to this issue, , the Government of "Jokowi"has launched a house development program of 1 million units yearly in April 2015. Furthermore, this program is one of the 10 (ten) priority programs in 2016. The details of providers, users and financing sources can be seen in table 2 as follow. 
Tabel-2: Providers, Users and source of Financing Affordable Public Housing Program 2015.

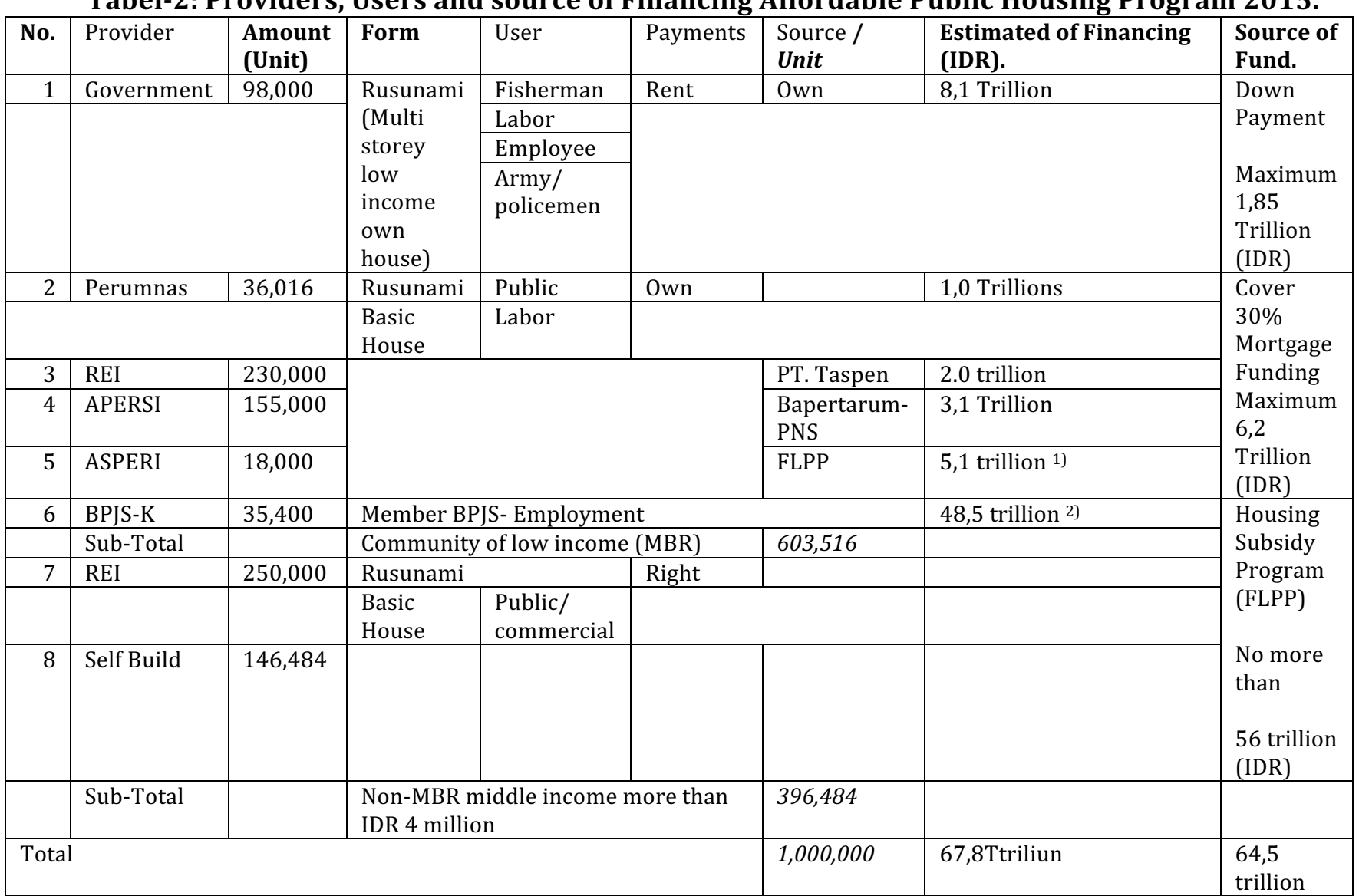

Source: D G Housing Financing (Ministry of Public Works and Hosing Development), 13 August 2015, (calculated)

Note: 1 ) The Ministry of PUPR (Public Works and housing Dev.) has proposed an additional FLPP funding for 2015 of $5 \mathrm{~T}$ to the Ministry of Finance through letter No.KU.01.05-Mn / 08 dated January 7, 2015 but not accommodated in the Revised State Budget 2015. In addition the Government allocates Rp. 220 Billion in FY 2015. This fund is to meet the financing needs for the reduction of the FLPP mortgage rates from $7.25 \%$ to $5 \%$, and the down payment to 1\%. 2) Revised PP (government Regulation) No.99 Year 2013 is required to change the placement of property investment funds from $5 \%$ to $30 \%$;

Table-2 above illustrates that the details of the implementation of this program consists of 2 (two) programs, namely: i) the program for MBR of 603,516 units, and ii) Non MBR program of 396,484 Units. The details of the MBR program consist of: i) Development carried out by the Government of 98,300 units, ii) The development is carried out by Perumnas of 36,016 units, iii) The development is carried out by the Regional Government of 30,000 units. The REI, APERSI, ASPERI, and BPJS-T (SociaL Security Governing Body on Employement) programs amounted to 230,000 units, 155,000 units, 18,800 units and 35,400 units respectively. While for Non MBR program will be built amounted to 396,484 units with the division of REI 250,000 units and the community 146,484 units. (Ministry of PUPR (Public Works, 2015).

\section{Target of housing development for MBR}

Furthermore, based on Permenpera no. 27 of 2012 and Permenpera no. 28 Year 2012 stated that what is meant by MBR is society having income from IDR. 3.500.000, -and up to IDR. 5.500.000. The classification of development targets can be seen in the table below. 


\section{Table - 3: Target Housing Development based on Family Decile}

\begin{tabular}{|c|c|c|c|c|c|}
\hline $\begin{array}{l}\text { Family } \\
\text { Decile }\end{array}$ & $\begin{array}{l}\text { Montly Family } \\
\text { Income } \\
\text { (Million IDR) }\end{array}$ & $\begin{array}{l}\text { Monthly Family } \\
\text { Expense } \\
\text { (Million IDR) }\end{array}$ & $\begin{array}{c}\text { Monthly } \\
\text { saving } \\
\text { (Million IDR) }\end{array}$ & $\begin{array}{l}\text { Monthly Housing } \\
\text { Investment } \\
\text { (Million IDR) }\end{array}$ & Interventions policy \\
\hline Decile1 & 1.2 & 1.2 & $0 \%$ & 0.0 & $\begin{array}{l}\text { Down payment and } \\
\text { mortgage rate subsidy }\end{array}$ \\
\hline r 2 & 1.8 & 1.4 & $21 \%$ & 0.4 & $\begin{array}{l}\text { Funding/ GoV. } \\
\text { Expenditure }\end{array}$ \\
\hline Decile3 & 2.1 & 1.6 & $24 \%$ & 0.5 & $\begin{array}{l}\text { Funding/ GoV. } \\
\text { Expenditure }\end{array}$ \\
\hline Deciel4 & 2.6 & 1.8 & $30 \%$ & 0.8 & $\begin{array}{l}\text { Financing state } \\
\text { budget/ } \\
\text { Subsidy } \\
\text { mortgage rate }\end{array}$ \\
\hline Dcsil5 & 3.1 & 2.1 & $34 \%$ & 1.0 & $\begin{array}{l}\text { Financing state } \\
\text { budget/ } \\
\text { subsidy mortgage rate }\end{array}$ \\
\hline Decile6 & 3.6 & 2.3 & $34 \%$ & 1.3 & No subsidy \\
\hline Deciel7 & 4.2 & 2.7 & $36 \%$ & 1.5 & No subsidy \\
\hline Deciel8 & 5.2 & 3.2 & $39 \%$ & 2.0 & No subsidy \\
\hline Deciel9 & 7.0 & 4.3 & $39 \%$ & 2.7 & No subsidy \\
\hline Decile10 & 13.9 & 8.2 & $41 \%$ & 5.7 & No subsidy \\
\hline $\begin{array}{l}\text { On } \\
\text { Average }\end{array}$ & 4.5 & 2.9 & $30 \%$ & 1.9 & \\
\hline
\end{tabular}

Source: CBS-WB, (DG of Financing, 2015)

\section{The development of housing finance schemes}

In Article 1, paragraph 24 of Law No. 1 of 2011 on Housing and Settlement Area states that the Low Income Society hereinafter abbreviated as MBR is a society with limited purchasing power so that it needs to get government support to obtain a house. In other words, MBR is a society that has: i) limited purchasing power, ii). Needs government support iii) obtaining a house (single, array, stack).

The form of ease is set forth in the credit agreement or financing agreement for the acquisition of houses for MBR as set out in paragraph (4). For the implementation of the provisions set forth in paragraph (5) which stipulates the provisions concerning the MBR criteria and requirements for the ease of obtaining housing for MBR as referred to in paragraph (2) and paragraph (3) shall be regulated by Ministerial Regulation

The government continues to develop financing schemes from various sources available to encourage the purchasing power of underprivileged communities through various types of subsidized KPR. The development of housing finance assistance scheme can be seen in table-4 below. 
Table-4: Development of Housing Financing Subsidy Scheme

\begin{tabular}{|c|c|c|c|c|c|c|c|c|}
\hline \multicolumn{2}{|l|}{ PERIOD } & \multirow{2}{*}{$\begin{array}{l}\text { Mortgate Rate } \\
\text { Subsidy }\end{array}$} & \multicolumn{6}{|c|}{ Scheme of financing subsidy } \\
\hline $\begin{array}{l}\text { PELITA } \\
\text { (5-year } \\
\text { plan) }\end{array}$ & Year & & $\begin{array}{l}\text { Equity } \\
\text { Partici } \\
\text { pation }\end{array}$ & $\begin{array}{c}\text { World } \\
\text { Bank }\end{array}$ & $\begin{array}{l}\text { Central } \\
\text { Bank } \\
\text { liquidly }\end{array}$ & $\begin{array}{l}\text { Investment } \\
\text { Account } \\
\text { Fund }\end{array}$ & Banks & $\begin{array}{c}\text { State } \\
\text { Budget }\end{array}$ \\
\hline II/III & $1976-1986$ & $\begin{array}{l}\text { Gov.\& Private Housing } \\
\text { Dev. }\end{array}$ & $\sqrt{ }$ & & $\sqrt{ }$ & & $\sqrt{ }$ & \\
\hline III/IV/V & 1986-1991 & $\begin{array}{l}\text { Gov.\& Private Housing } \\
\text { Dev. }\end{array}$ & $\sqrt{ }$ & & $\sqrt{ }$ & & $\sqrt{ }$ & \\
\hline $\mathrm{V} / \mathrm{VI}$ & 1991-1999 & Interest Rate subsidy & & $\sqrt{ }$ & $\sqrt{ }$ & & $\sqrt{ }$ & \\
\hline & $1999-2000$ & Interest Rate subsidy & & & $\sqrt{ }$ & $\sqrt{ }$ & $\sqrt{ }$ & \\
\hline & $2000-2001$ & Interest Rate subsidy & & & & $\sqrt{ }$ & $\sqrt{ }$ & \\
\hline & 2002 & Interest Rate subsidy) & & & & $\sqrt{ }$ & $\sqrt{ }$ & $\sqrt{ }$ \\
\hline & $2003-2010$ & $\begin{array}{l}\text { Interest Rate subsidy } \\
\text { and down payment } \\
\text { subsidy }\end{array}$ & & & & & $\sqrt{ }$ & $\sqrt{ }$ \\
\hline & $2010-2014$ & Margin rate subsidy & & & & & $\sqrt{ }$ & $\sqrt{ }$ \\
\hline & $2015-2019$ & $\begin{array}{l}\text { Complete housing } \\
\text { subsidy scheme }\end{array}$ & & & & & $\sqrt{ }$ & $\sqrt{ }$ \\
\hline
\end{tabular}

Source: Ministry Public Works and Housing Development,2016

Table- 4 above illustrates the executing bank is a financial institution that distributes to the community who do not have a home. Meanwhile government provides fiscal and non-fiscal support. Explicitly the government through APBN had provided subsidy on interest discount since 2003. In the housing program of 2015-2019, the government provides various subsidies such as Housing Financing Liquidity Facility (FLPP), interest subsidy (SSB) and Down Payment subsidy (BUM). In detail the budget allocation plan is shown in appendix 2 tables l-2.

\section{ANALYSIS OF HOUSING FINANCING SOURCE OF MBR}

\section{Financing Policies and Strategies}

The financing aspect to prioritize this priority program, the government launched 3 (three) strategically policies, namely: i) creating affordable and accessible housing financing; ii) creating a conducive climate for improving supply side performance; and 3) ensuring the availability of low-cost funds in the long term. The complete stratecical policies and strategies for housing financing 2015 - 2019 are in table l-1 in appendix-1. In other words, the government fasilties to encourage the availability of demand-based housing (Demand) and supply side (Supply) supported by a conducive long-term financing system. To implement this strategy, the government is improving institutional governance both in terms of strengthening existing institutions and establishing new institutions. Improvement of institutional governance is expected to accelerate the procurement of decent housing in terms of demand and supply side responsively.

On the demand side, the Government stimulate Public purchasing power by providing various forms of subsidies. In addition, government is not only acts as a regulator but also as joint operators of private and community for integrating exiting policies to provide affordable house prices. On the supply side, as a regulator, the government established Kemenpera (Ministry of Public Housing) merged to the Ministry of Public Works that became the Ministry of Public Works and Public Housing (Kemen PUPR) in 2014. This Ministry is responsible for implementing the existing laws and regulations such as the 1945 Constitution, Law No. 11 of 2005, Law No. 1 of 2011, Law No. 20 of 2011 and its implementing regulations. While as an operator, government estblished Public Corporation (Perum) National Housing in 1974 and Public Service Agency (BLU) Central Management of Housing Financing Fund (PPDPP) which is the Work Unit (Satker) within the Ministry of PUPR Public Works and housing development. In 
short, Institutional setting on optimizing source of funding to finance affordable housing for MBR is government strategy to reduce a shortage of public housing.

In detail the government policies and strategies contained in the seventh section of article 54 in paragraphs as follows:

(1) The Government is obliged to fulfill the housing requirement for MBR.

(2) In order to meet the housing needs for MBR as referred to in paragraph (1), the Government and / or local government shall provide facilities for the construction and acquisition of houses through a gradual and sustainable housing development planning program.

(3) The ease and / or assistance for building and obtaining housing for MBR as referred to in paragraph (2) may be in the form of: a. Subsidy for the acquisition of a house; B. stimulant self-help house; Incentive taxation in accordance with the provisions of laws and regulations in the field of taxation; Permissions; E. Insurance and guarantees f. land information legalize land letter; and / or, facilities, and public utilities.

4) the ease of provision as referred to in paragraph (3) letter a shall be stated in the credit agreement or financing agreement for the acquisition of the house for low income community

(5) provisions on MBR criteria and requirements for ease of of houses for MBR as referred to in paragraph (2) and paragraph (3) shall be regulated by Ministerial Regulation

In summary, the above clause describes the related policy of meeting MBR's supply and demand for home procurement. Particularly in paragraph 5 raises the criteria of the main discourse on the understanding of the limitations of purchasing power and which institutions are entitled to compile considering that several institutions have been arranged in relation to the MBR. Criteria that have been compiled are listed in Figure- 1 and table- 4 above.

Theoretically, the analysis of the optimal of the source of housing finance with the affordable price can be analyzed by 2 (two) concepts, namely: i) Supply Chain Concept and ii) The Concept of Institutional Relations Governance.

\section{Partnership Analysis in the MBR Housing Supply Chain}

The basic concept of supply chain is presented by Agustinus Purna Irawan in Supply Chain Management Textbook (Faculty of Engineering Tarumanagara University, August 2008). This concept sets forth the Supply Chain Management Philosophy (SCM). The philosophy is how to manage supply of goods from raw material sources to customers as an integrative entity rather than managing supply of goods as a series of separate activities.

Develop partnerships and co-partnership with organizations both upstream and downstream. The diagram of the relationship between partnership and Co-Maker ship is shown in Figure -1 below. 
Figure-1: Partnership and Co-partnership Relationships.

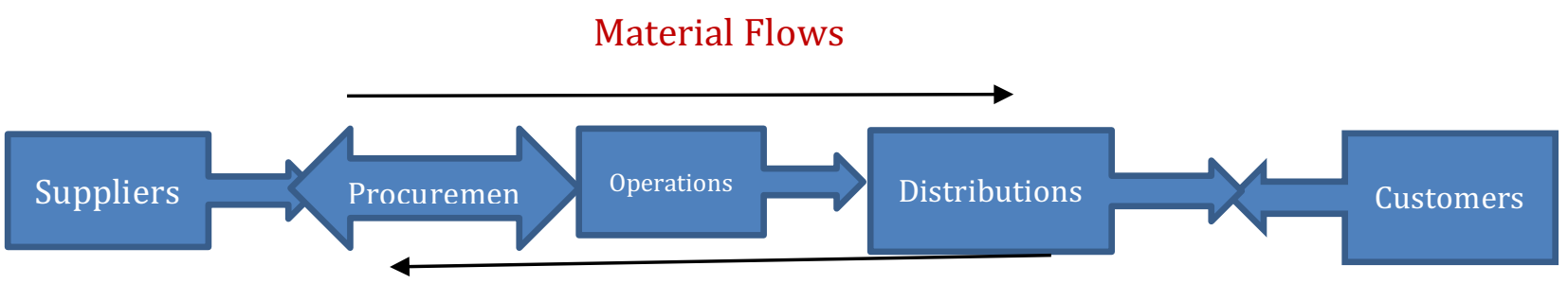

The needs of Information flows

Source: Agustinus, page. 12, 2008.

This model is useful for identifying some of the main activities and supporters commonly encountered in various business activities. The value chain only highlights some special activities that enable the company to create value and thus make the model a useful tool for simplifying analysis. To optimize the source of bank financing for Home Ownership Loan (KPR) and funding for developers in order to affordable housing prices, APBN financing acts through BLU PPDPP and PT SMF. Full picture based on the concept of supply chain flow can be seen in Figure-2 below.

Figure-2: The Role of State Budget in Optimizing Source of Housing Financing of MBR

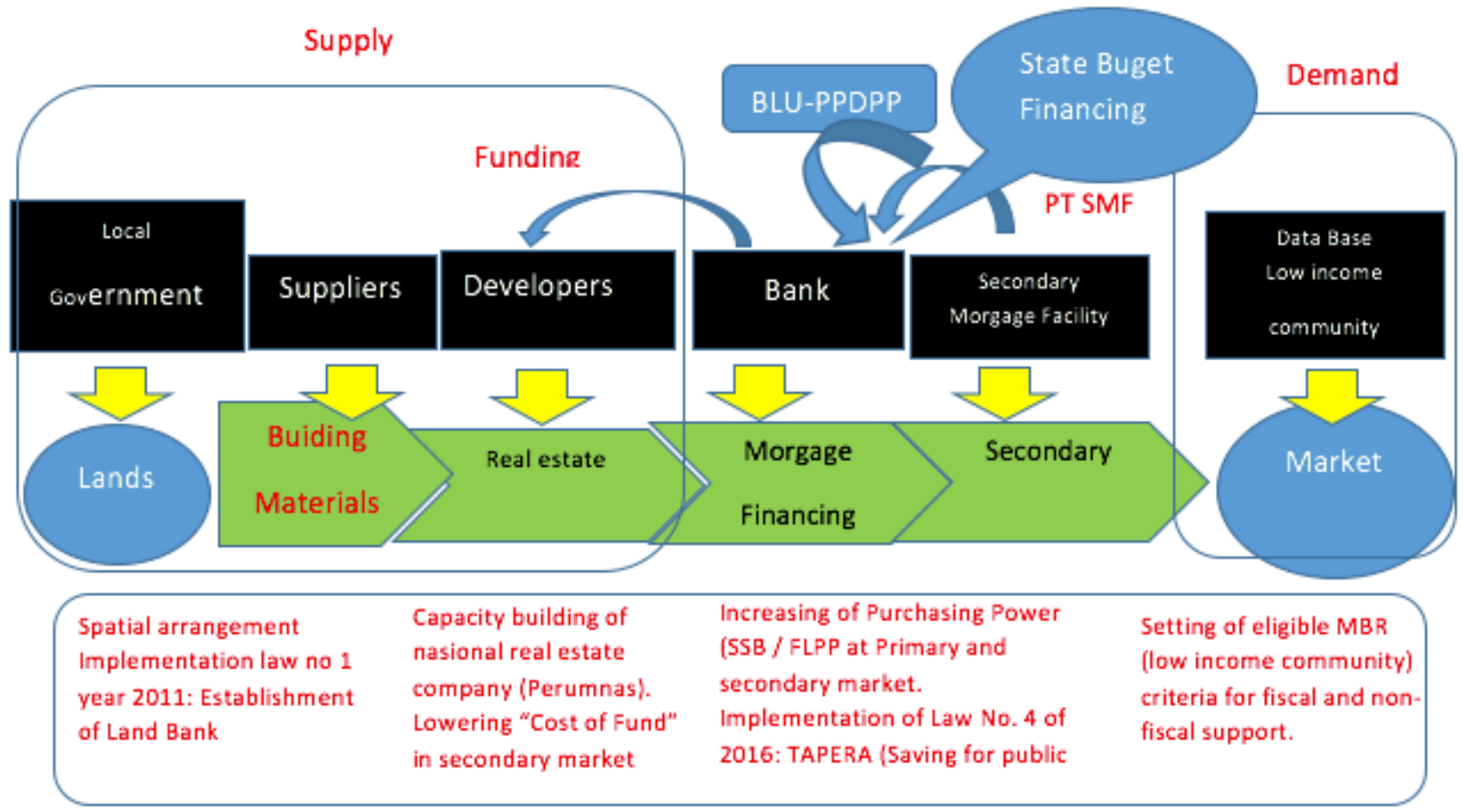

Source: Annalists Team, BLU PPDPP, 2016, (modified)

Note: BLU PPP: Revolving Fund Agency on Housing Development Financing

As shown figure-2: above illustrates the role of APBN (state budget) in optimizing the source of housing financing for MBR through BLU - PPDPP and. PT SMF (Sarana Multigriya Finansial)

\section{Revolving Funds Public Company - Centre of Agency Revolving fund for public housing (BLU - PPDPP)}

The Center of Housing Financing Fund Management (PPDPP) is a Work Unit (Satker) under the supervision of the Ministry of Public Works and Public Housing. This center was established under the Decree of the Minister of Finance No. 112 / KMK.05 / 2016 dated February 19, 2016, 
the PPDPP is stipulated as a Government Institution applying the Financial Management of the Public Service Agency. PPDPP has the main duty to channel and manage government investment funds for housing finance for Low Income Communities (MBR). The allocation of state budget funds sourced from the Directorate General of Treasury is channeled through PPDPP to finance home ownership for MBR with a revolving fund management scheme that channeled in collaboration with banks through an FLPP facility with an "executing" pattern.

KPR -FLPP (Mortgate rate subsidy) is a program of assistance and ease of acquisition of houses for MBR (Low income community) with low interest rate of 5\% fixed, credit period up to 20 years, low interest, free of VAT and free of insurance premium and fire insurance. MBR who have obtained KPR FLPP assistance must occupy the house, if MBR does not occupy the house (empty, transferred or leased), will be subject to two sanctions namely criminal sanctions based on Article 152 UU No. 1 of 2011 on housing and Settlement Area, with the largest fine 50 million rupiah and sanctioned the return of assistance that has been obtained in order to channel the channeling in collaboration with the banking through housing financing liquidity facility (FLPP) with the executing-scheme.

The points of legal basis for the implementation of FLPP is as follows:

- Regulation of the Minister of Public Works and Public Housing No. 20 of 2014 dated 12$12-2014$

- Regulation of the Minister of Public Works and Public Housing Number 21 of 2014 dated 12-12-2014

- Regulation of the Minister of Public Works and Public Housing No. 20 of 2015 dated 2304-2015

- Regulation of the Minister of Public Works and Public Housing No. 32 of 2015 dated 2304-2015

- Decree of the Minister of Public Works and Public Housing No. 257 of 2015 dated 2304-2015 : PT Sarana Multigriya Finansial (PT SMF).

The establishment of PT SMF is stated in Presidential Decree 1/2008 Jo.19 / 2005, and the Regulation of the Financial Services Authority (POJK) No.23 / P0JK.04 / 2014. In this mandate PT SMF plays a role in strengthening Indonesia's financial markets and supporting the development of domestic investor base PT SMF plays a role in channeling loans to banks through funding from the capital market. Banks that get loan disbursements are not only conventional banks but also sharia banks and regional banks. In addition, SMF serves to encourage the banking sector to conduct securitization through the Issuance of AssetGenerated Securities issuing instruments (EBA-SP). The advantage of banking securitization is to reduce credit risk on mortgages due to the risk of mismatch. Through securitization, banks get their liquidity back so it can be channeled again to the community in the form of KPR. In addition, debtors whose receivables are securitized receive long-term financing from the capital market

\section{Partnership Analysis in the concept of Good Corporate Governance}

Given the above picture 2 suggests a partnership relationship in the concept of supply chain then it is necessary to put forward the relationship of partnership in the concept of Governance. In the concept of Good Corporate Governance, Stakeholders or stakeholder procurement, there are 3 (three) parties namely i) State or bureaucrats, ii) Industry or market actors and iii) Community or community. These three stakeholders have a characteristic business process based on their vision and mission. Ideally, the interaction of the three stakeholders can be seen in Figure-3 below. 
Figure -3: Multi Partnership Governance framework

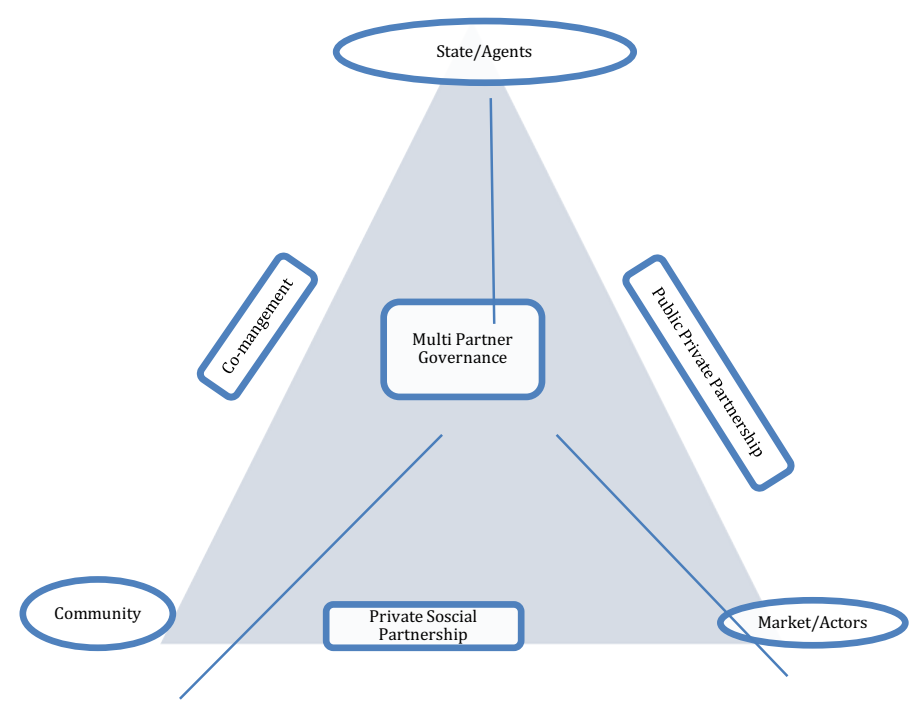

Source: Lemos and Agrawal, 2009.

Figure 3.2.1 above provides the concept of developing public institutions (local, national and international) to anticipate climate change resulting from population growth (Dellas et al., 2011a). This paper attempts to analyze housing development issues using the concepts introduced by Lemos and Agraval in 2009. This concept introduces the governance of interactions between agents and actors. Actors refers to the individuals, organizations, and networks that participate in decision making related to the earth system governance (Biermann et al., 2009a). An agent (authoritative actor) is an actor who possesses the ability to prescribe behavior and to obtain the consent of the governed. Authority refers to legitimacy and capacity to exercise power, while power refers to the capacity to influence an outcome of events, with or without the legitimacy to do so. Agents contribute here to purposeful steering of the constituents, either indirectly (by influencing the decisions of other actors) or directly (by making steering decisions).

In the context of public housing procurement the government's vision is to provide a proper home at an affordable price. While the vision of market participants is "going concern" or gain a sustainable advantage. While the vision of community institutions such as environmental NGOs is the availability of homes that are habitable and environmentally friendly. The partnership between government and business or developer is public private partnership (PPP) or Public Private Partnership (PPP). The partnership between Community and Business Actors is Social Responsibility and Environment (CSR) or Corporate Social Responsibility (CSR). While the mutual benefit between government and society is community development program or Community Development (CD)on infrastructure. The program that was launched was Kampongs Improvement Program (KIP). This program is implemented by the Directorate of Cipta Karya (construction Design) which has international funding support such as World Bank (WB) and Islamic Development Institutionally, stakeholders or public interest in optimizing source of financing consist of 3 (three), namely: i) Public Development Financing Agency of Housing Development (BLU-PPP), ii)developers and iii) Executing Bank. The relationship between these three institutions is contained in Figure 4 below: 


\section{Figure -4: Relationship among Institutions in the affordable price in public housing}

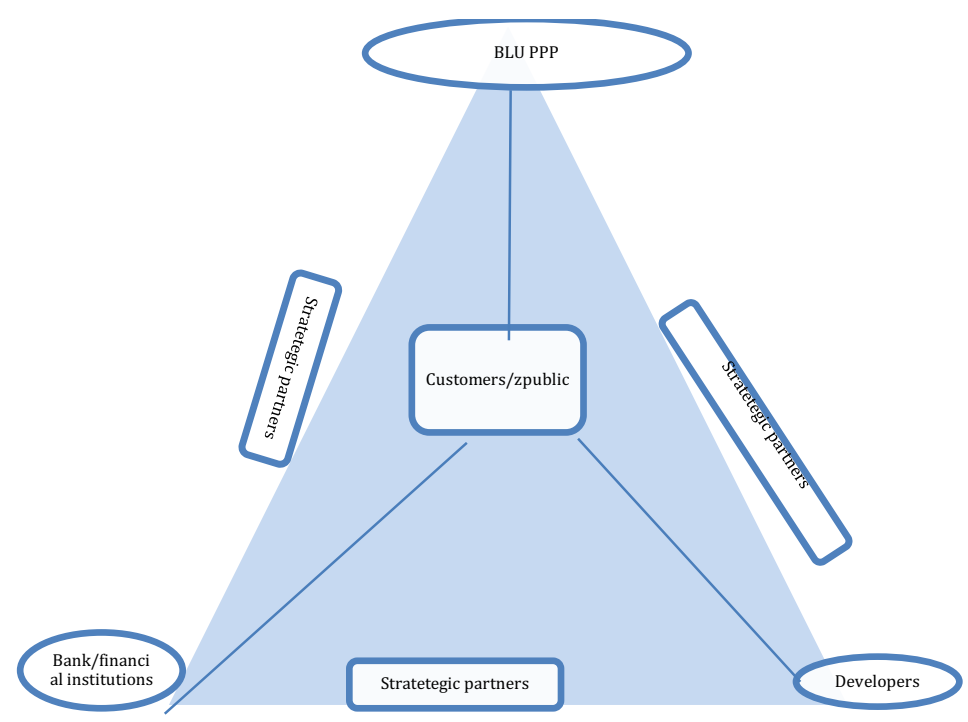

Source: (Analyst Team, BLU-PPP, 2016)

In addition, the BLU-PPDPP analyst team has identified the role of among stakeholders to improve its role on its strategic partnerships as follows:

Table-5: Strategic partnerships among stakeholders to improve its role

\begin{tabular}{|c|c|c|}
\hline No. & Stakeholders & Improve its role on \\
\hline 1. & Insurance & $\begin{array}{l}\text { - Marketing and socialization together } \\
\text { - Provision of long-term funds for implementing banks. } \\
\text { - Home Ownership Credit Insurance. } \\
\text { - Provision of markets through insurance participants database. }\end{array}$ \\
\hline 2. & Bank & $\begin{array}{l}\text { - FLPP (Housing subsidy) program implementers } \\
\text { - Affordable mortgage supplier partners } \\
\text { - Provide bank portion fund for KPR disbursement } \\
\text { - Partner providers and builders of housing projects } \\
\text { - Ensure supply is fulfilled } \\
\text { - Providers of building materials for housing projects. } \\
\text { - Ensure housing supply is matched } \\
\text { - Providers and preparation of secondary financing } \\
\text { - Providers of long-term funds through secondary financing }\end{array}$ \\
\hline 3. & Local Government & $\begin{array}{l}\text { - Provision of land for the construction of housing projects } \\
\text { - Providers of long-term funds for Regional Development Banks (BPD). } \\
\text { - Land bank initiator }\end{array}$ \\
\hline
\end{tabular}

\section{FINDINGS AND RECOMMENDATIONS}

In conclucion, there are 3 (three) strategically aspect in public housing development policies should be synergized for optimizing its source of fund in the future. The 3 (three) aspects might be described as: i) the existing regulatory framework, ii) potential sources of funding to finance affordable public housing, and iii) experience in the financing scheme. The synergized among those three aspects are the corner stones of the success of the MBR housing development program. The regulatory framework stated in Law No. 1 of 2011 on Housing and Settlement Area of targeting effectiveness (Article 1 paragraph 24 and article 54 paragraph (2), (3) and (5) . While optimizing the sources of financing listed on Article 126. The Government of Indonesia has experience in housing financing schemes for low-income people (MBR) more than 4 (four) decades, while the sources of funding through implementing banks product in the 
form of: i) PMP (equity participation), ii) RDI (account of Investment Fund) , iii ) KLBI (Central Bank Liquidity Aids), iv) World Bank loans, and v) State budget expenditure allocation.

Conceptually optimizing these sources of fund might be applied in 2 (two) approaches, namely: 1) concept of supply chain, and ii) concept of partnership or governance. The concept of supply chain is how to meet demand side (MBR) and supply side (developer) while the concept of governance brings together the vision of institutional mission based on partnerships. The first concept should be supported by a long-term financing scheme. While the concept of Good Corporate Governance, Stakeholders or stakeholder procurement, there are 3 (three) parties namely i) State or bureaucrats, ii) Industry or market actors and iii) Community or community. These three stakeholders have a characteristic business process based on their vision and mission

Hopefully, the first concepts generate more conducive climate to promote the availability of affordable price in public housing. Strategically, to promote institutional long-term financing system suppoted by the fiscal policies to stimulate both in managing of spending and financing towards more efficiently. In terms of expenditures, the government provides subsidies for down payments and has establihed FLPP (Housing Financing Liquidity Facility) under the Public Service Agency (BLU) mechanism, which serves for primary financing. While the government financing is represented by PT Sarana Multigriya Finansial (SMF) for Secondary financing. The integration of primary and secondary financing needs to be constantly encouraged both from a supply chain approach or a governance or partnership approach.

In the future optimization of funding sources to finance public funding might be implemented as a strategically step to improve the effectiveness of the target based on better criteria based on the home as the basic needs and focus the ownership of the house instead of as an investment portofolio. 


\section{Attachment-1}

Tabel-L1: Policy and strategy affordable price in public housing program year 2015 -2019

\begin{tabular}{|c|c|c|}
\hline NO & POLICY & STRATEGY \\
\hline 1 & Development & $\begin{array}{l}\text { 1) Preparation of Public Housing Savings Bill (Tapera) or Tapera network in the } \\
\text { SJSN system; } \\
\text { 2) Preparation of RPP and Raperpres derived from Tapera Bill; } \\
\text { 3) Preparation of RPP originating from Law No. } 1 \text { of } 2011 \text { concerning Housing and } \\
\text { Settlements; } \\
\text { 4) Rules of Regulation Regarding facilitation of housing finance assistance. }\end{array}$ \\
\hline 2 & $\begin{array}{l}\text { Regulation And Policy To } \\
\text { Create A Conducive Climate }\end{array}$ & $\begin{array}{l}\text { 1) Facilitating the issuance of regulations that may encourage Bank BTN to become } \\
\text { a Bank focusing on housing finance; } \\
\text { 2) Encouraging the placement of Taperum PNS funds, TWP TNI / Polari funds at } \\
\text { Bank BTN; } \\
\text { 3) Encourage placement of Haj funds, Pension Fund, Insurance Fund and BPJS Fund } \\
\text { at Bank BTN. }\end{array}$ \\
\hline 3 & $\begin{array}{l}\text { Greater BTN Bank Role } \\
\text { Improvement in the } \\
\text { distribution of housing finance } \\
\text { assistance }\end{array}$ & $\begin{array}{l}\text { 1) Increased cooperation with PT SMF in order to increase the capacity of } \\
\text { stakeholders of housing finance; } \\
\text { 2) Encouraging the revision of Per- no. } 1 \text { year } 2008 \text { juncto } 19 / 2005 \text {. }\end{array}$ \\
\hline 4 & $\begin{array}{l}\text { Increased role of secondary } \\
\text { housing finance company } \\
\text { (PT.SMF) }\end{array}$ & $\begin{array}{l}\text { 1) Establishment of Tapera Management Board or encourage amendment of UU } \\
\text { SJSN and UU BPJS; } \\
\text { 2) Development of the utilization of Tapera funds to facilitate the MBR of the } \\
\text { informal sector, the provision of advances and the provision of land. }\end{array}$ \\
\hline 5 & $\begin{array}{l}\text { The preparation of Tapera's } \\
\text { operational infrastructure or } \\
\text { the integration of people's } \\
\text { housing savings into the SJSN }\end{array}$ & $\begin{array}{l}\text { 1) Facilitating the publication of a regulation that can encourage the establishment } \\
\text { of Hajj, the Pension Fund, the Insurance Fund, and the BPJS Fund in a financial } \\
\text { instrument that supports the financing of housing; } \\
\text { 2) Encouraging the placement of Taperum-PNS, and Dana TWP TNI / POLRI in Bank } \\
\text { BTN. (National Saving Bank) }\end{array}$ \\
\hline 6 & $\begin{array}{l}\text { Long-term fund placement on } \\
\text { financial instruments that } \\
\text { support housing finance }\end{array}$ & $\begin{array}{l}\text { 1) Distribution of housing finance assistance to facilitate the construction of } \\
9,000,000 \text { units of public houses (houses, sukunami (storey apartment), and } \\
\text { sewabeli (leasing)); } \\
\text { 2) Distribution of housing finance assistance to facilitate the construction of } \\
\text { 450,000 households; } \\
\text { 3) Expansion of co-operation with the Ministry of Public Service and a related } \\
\text { authority to increase the issuance of KPR FLPP; } \\
\text { 4) Development of the financing of housing in the best way from the manager and } \\
\text { the supplement (credit construction); } \\
\text { 5) Development of housing finance assistance for sector-specific MBR; } \\
\text { 6) Developing and providing a total of } 476,000 \text { units for certain MBR groups; } \\
\text { 7) Encourage the formation of specialized MULTIFICINES KPR program; } \\
\text { 8) Improvement of technical guidance activities, particularly to Institutions Bank } \\
\text { (LKBB) and (Developers); } \\
\text { 9) Development of institutionalism that supports housing finance assistance for } \\
\text { informal sector in MBR; } \\
\text { 10) Development of the guarantee of KPR-FLPP Home self- financing (Swadaya); } \\
\text { 11) Facility linkage between the Financial InstitutionBank / Non-Bank (LKB / } \\
\text { LKBB); } \\
\text { 12) Empowerment of LKB / LKBB. (Financial institution: Banks and Non -Banks. }\end{array}$ \\
\hline 7. & $\begin{array}{l}\text { Improving role of local } \\
\text { government on public housing } \\
\text { financing. }\end{array}$ & $\begin{array}{l}\text { 1) Enhancement of technical guidance to Provincial Governments, District } \\
\text { Government and Provincial Governments; } \\
\text { 2) Cooperation with several Metropolitan City and City for preparing the role of } \\
\text { Local Housing Services (BLUD) financing housing; } \\
\text { 3) Facilitation of the City in identifying the feasible home projects shall be financed } \\
\text { by the regional balances; } \\
\text { 4) Facilitation of the implementation of BLUD to housing financing in particular the } \\
\text { city / regency which having adequate fiscal capacity }\end{array}$ \\
\hline
\end{tabular}

Source: Ministry of Public Works and Housing Development, 2015. 


\section{Attachment 2}

Table-12: Target and allocation for housing discount mortgage rate subsidy (KPR-FLPP) year 2015 - 2019.

\begin{tabular}{|c|c|c|c|c|c|c|c|c|c|}
\hline \multirow{3}{*}{$\begin{array}{l}\text { TYPES OF } \\
\text { HOUSING } \\
\text { HOUSING } \\
\text { FINANCE }\end{array}$} & \multirow[t]{3}{*}{ Unit } & \multicolumn{8}{|c|}{ TARGET AND ESTIMATED BUDGET } \\
\hline & & \multicolumn{2}{|c|}{2015} & \multicolumn{2}{|c|}{2016} & \multirow[t]{2}{*}{2017} & \multirow[t]{2}{*}{2018} & \multirow[t]{2}{*}{2019} & \multirow[t]{2}{*}{ TOTAL } \\
\hline & & $\begin{array}{l}\text { Medium- } \\
\text { Plan }\end{array}$ & $\begin{array}{l}\text { Budget } \\
\text { allocation }\end{array}$ & $\begin{array}{l}\text { Medium- } \\
\text { Plan }\end{array}$ & $\begin{array}{l}\text { Budget } \\
\text { allocation }\end{array}$ & & & & \\
\hline \multicolumn{10}{|c|}{ 1. Advance Money Assistance for MBR * } \\
\hline $\begin{array}{l}\text {-Number of home } \\
\text { buyers Get Access } \\
\text { (BUM) }\end{array}$ & Household & 55,000 & 55,000 & 106,500 & 337,839 & 124,250 & 124,370 & 65,880 & 476,000 \\
\hline Budget (x IDR 1M) & $I D R$ & 220,000 & 220,000 & 479,250 & $1,351,000$ & 621,250 & 684,035 & 395,280 & $2,399,815$ \\
\hline \multicolumn{10}{|c|}{ 2. Housing Finance Assistance (KPR-FLPP) for MBR } \\
\hline $\begin{array}{l}\text {-The number of } \\
\text { homebuyers who } \\
\text { get the financing } \\
\text { assistance of the } \\
\text { housing Housing } \\
\text { KPR is genuine }\end{array}$ & Household & 130,000 & 65,625 & 150,000 & 89,186 & 175,000 & 173,500 & 91,500 & 720,000 \\
\hline $\begin{array}{l}\text {-The number of } \\
\text { homebuyers who } \\
\text { get the help of the } \\
\text { housing finance of } \\
\text { the KPR. }\end{array}$ & Household & - & & 25,000 & & 50,000 & 75,000 & 26,500 & 176,500 \\
\hline $\begin{array}{l}\text {-The number of } \\
\text { homebuyers who } \\
\text { get the help of } \\
\text { housing finance is } \\
\text { supportable }\end{array}$ & Household & - & - & & & & 1,500 & 2,000 & 3,500 \\
\hline $\begin{array}{l}\text {-The number of } \\
\text { housing units that } \\
\text { received the } \\
\text { Construction } \\
\text { Credit financing } \\
\text { facility }\end{array}$ & $\begin{array}{l}\text { Unit of } \\
\text { house }\end{array}$ & - & & 1,000 & & 1,500 & 2,000 & 1,500 & 6,000 \\
\hline $\begin{array}{l}\text {-The number of } \\
\text { homebuyers who } \\
\text { get help from } \\
\text { housing KPR } \\
\text { Swadaya (self } \\
\text { financing) }\end{array}$ & Household & - & & 50,000 & & 150,000 & 200,000 & 50,000 & 450,000 \\
\hline Budget (x Rp 1M) & $I D R$ & $10,115,391$ & $5,106,330$ & $25,070,893$ & $9,227,000$ & $42,738,884$ & $58,136,629$ & $26,030,835$ & $162,092,632$ \\
\hline $\begin{array}{l}\text { SUBSIDY BUDGET } \\
\text { HEARING } \\
\text { ASSURANCE (BA } \\
\text { 033.08 / BA } \\
999.07) \\
\end{array}$ & & 220,00 & 220,000 & 479,250 & $1,351,000$ & 621,250 & 684,035 & 395,280 & $2,399,815$ \\
\hline $\begin{array}{l}\text { FLPP BUDGET (BA } \\
\text { 999.03) }\end{array}$ & & $10,115,391$ & $5,106,330$ & $25,070,893$ & $9,227,000$ & $42,738,884$ & $58,136,629$ & $26,030,835$ & $162,092,632$ \\
\hline $\begin{array}{l}\text { TOTAL BUDGET } \\
\text { SUBSIDY AND } \\
\text { FLPP (BA 999.03 } \\
\text { AND 999.07) }\end{array}$ & & $10,335,391$ & $5,326,330$ & $25,550,143$ & $10,578,000$ & $43,360,134$ & $58,820,664$ & $26,426,115$ & $164,492,447$ \\
\hline
\end{tabular}

Source: Public Works and Public Housing Development,2015 


\section{References}

Agustinus Purna Irawan, Buku Ajar Manajemen Rantai Pasokan Fakultas Teknik Universitas Tarumanagara Agustus 2008

Arya Mandala, SMF Bidik Pembiayaan Perumahan Rp 6,1 Triliun, Indonesian Industry January 29, 2016, 10:37 am.

Austin, Nick, Chief Executive Officer, ACIAR Washington DC, Membuat Rantai Nilai Lebih Berpihak pada Kaum Miskin, Buku Pegangan bagi Praktisi Analisis Rantai Nilai, 28-29 May 2014.

Dellas, E., Pattberg, P., Betsill, M. 2011a. Agency in Earth System Governance: Refining a research agenda, International Environment Agreements, 11: 85- 98

Doyoharjo, Anggo, Sekuritisasi Aset sebagai alternative sumber Pembiayaan (merubah Piutang Menjadi Surat Berharga, Jurnal Wacana Hukum, Unsri, Volume VII, No 2, 2008, halaman 32 -42.

Griffiths, Jesse, 'Leveraging' private sector finance: How does it work and what are the risks? Bretton Woods Project, April 2012.

Lemos, M.C., and Agrawal, A., 2009. 'Environmental governance and political science' in: Delmas M.A. and Young O.R., Governance of the Environment: New Perspectives, Cambridge University Press, UK

Nugroho Tri Utomo, Affordable Housing Finance Policies on Indonesia, Director of Housing and Settlement Ministry of National Development Planning Republic of Indonesia, Dirjen

Pembiayaan Perumahan, Kebijakan Bidang Pembiayaan Perumahan, Rapat Koordinasi Teknis (Rakostek)

Perencanaan Pengadaan Perumahan, Yogyakarta, 13 Agustus 2015.Kementerian

Keuangan RI, Hand out Pembahasan Program 1 juta rumah, Jakarta, 15 Mei 2015.Menteri Perencanaan Pembangunan Nasional /Bappenas, Pembangunan Perumahan tantangan, Visi, Dan Arahan Program, Jakarta, 25 November 2013.

Kemenko Kesra, Rapat Target Perumahan Masyarkat Bepenghasilan Rendah, UU no 11 tahun 2014 tentang Perumahan dan Kawasan Permukiman, 11 April 2014.

Direktorat Jenderal Anggaran Kementerian Keuangan, Peranan Apbn Dalam Mengatasi Backlog Perumahan Bagi Masyarakat Berpenghasilan Rendah (MBR), 2015. 